\title{
Is There Enough Evidence for Osteosarcopenic Obesity as a Distinct Entity? A Critical Literature Review
}

\author{
Jürgen M. Bauer ${ }^{1}$ - Alfonso J. Cruz-Jentoft ${ }^{2}$ - Roger A. Fielding ${ }^{3}$ • John A. Kanis ${ }^{4,5}$ - Jean-Yves Reginster ${ }^{6,7,8}$. \\ Olivier Bruyère ${ }^{6,7} \cdot$ Matteo Cesari $^{9} \cdot$ Roland Chapurlat $^{10} \cdot$ Nasser Al-Daghri $^{8} \cdot$ Elaine Dennison $^{11}$. \\ Jean-Marc Kaufman ${ }^{12}$. Francesco Landi ${ }^{13}$. Andrea Laslop ${ }^{14}$. Médéa Locquet ${ }^{6,7}$. Stefania Maggi ${ }^{15}$. \\ Eugene McCloskey ${ }^{16,17}$. Simone Perna ${ }^{18} \cdot$ René Rizzoli $^{7,19}$. Yves Rolland ${ }^{20} \cdot$ Mariangela Rondanelli $^{21} \cdot$ Pawel Szulc $^{22}$. \\ Bruno Vellas ${ }^{20} \cdot$ Mila Vlaskovska $^{23} \cdot$ Cyrus Cooper ${ }^{7,11,24}$
}

Received: 26 September 2018 / Accepted: 2 May 2019 / Published online: 16 May 2019

(c) The Author(s) 2019, corrected publication 2019

\begin{abstract}
The co-existence of impaired bone health (osteopenia/osteoporosis), reduced muscle mass and strength (sarcopenia), and increased adiposity (obesity) in middle-aged and older people has been identified in recent studies, leading to a proposal for the existence of "osteosarcopenic obesity" as a distinct entity. Evidence for the pathophysiological overlap of these conditions is mounting, although a causal relationship is yet to be established. Each component condition occurs frequently with increasing age, and with shared risk factors in many instances, thus, an overlap of these three conditions is not surprising. However, whether the concurrent existence of sarcopenia, osteoporosis and obesity leads to an increased risk of adverse musculoskeletal outcomes and mortality above and beyond the risks associated with the sum of the component parts remains to be proven and is a question of research interest. In this article, we review evidence for the existence of osteosarcopenic obesity including the current operational definition of osteosarcopenic obesity, prevalence, pathophysiology, outcomes and exploratory approaches to the management of components. We conclude that, there is insufficient evidence to support a discrete clinical entity of osteosarcopenic obesity at this time. To expand knowledge and understanding in this area, there is a need for consensus on a definition of osteosarcopenic obesity which will allow for identification, further epidemiological studies and comparisons between studies. Additionally, studies should assess whether the clinical outcomes associated with osteosarcopenic obesity are worse than the mere addition of those linked with its components. This will help to determine whether defining a person as having this triad will eventually result in a more effective treatment than addressing each of the three conditions separately.
\end{abstract}

Keywords Obesity $\cdot$ Osteoporosis $\cdot$ Sarcopenia $\cdot$ Osteosarcopenia $\cdot$ Sarcopenic obesity

\section{Introduction}

The rise in obesity prevalence over the last few decades poses a burdensome public health problem, with the combined overweight and obese population in many countries accounting for the majority of people, especially among the middle-age and older-age groups [1, 2]. Typically, all contributory factors to obesity, sarcopenia, and osteoporosisincrease in fat mass, decrease in lean muscle mass and muscle strength, and decrease in bone mass and function-occur

Jürgen M. Bauer

Juergen.Bauer@bethanien-heidelberg.de

Extended author information available on the last page of the article with "normal aging". Increased body fat can be present either as an overt overweight/obesity or fat redistributed into visceral organs and/or fat infiltrated into bone and muscle, which occurs especially with age and some chronic diseases $[3,4]$. While reducing body weight is the primary strategy for obese individuals, weight-reduction therapies may compromise the ability to preserve muscle function and mass [5].

Sarcopenia, is a progressive and generalized skeletal muscle disorder, which can be detected as low muscle strength and confirmed by the presence of low muscle quantity or quality $[6,7]$. Sarcopenic individuals have both decreased muscle mass and increased intra- and intermuscular fat: changes that are associated with mobility limitations in older people [8]. The co-presence of sarcopenia and obesity has 
been described in the literature as sarcopenic obesity [9]. Diminished physical performance leads to frailty, increased risk of falls, and subsequent fractures, causing a loss of independence, reduced quality of life, and greater morbidity and mortality [10]. The risk of frailty and disability in obese individuals with low muscle mass and function has been reported to be higher than that observed in non-obese counterparts with similar muscle alterations [11].

Osteoporosis, a systemic skeletal disease characterized by low bone mass and microarchitectural deterioration of bone tissue with a consequent increase in bone fragility, occurs frequently, particularly in older women. At the age of 50 years, the remaining lifetime probability of a major osteoporotic fracture in Sweden is $22 \%$ in men and $46 \%$ in women [12].

Sarcopenia and osteoporosis have similar risk factors that include genetics, endocrine function, and mechanical factors. Additionally, bone and muscle closely interact with each other not only mechanically but also metabolically. The combination of osteoporosis/osteopenia and sarcopenia has been termed osteosarcopenia [13-15]. It is unclear whether individuals with so-called osteosarcopenia are at greater risk of adverse clinical outcomes than those with sarcopenia or osteoporosis alone. In a small study of hip fracture patents, the 1-year mortality of those with osteosarcopenia (15.1\%) was higher than that of those with osteoporosis alone (5.1\%) or sarcopenia alone (10.3\%) [16]. Consistent with this observation, a study of patients admitted to intensive care reported that 1-year mortality was increased in individuals with sarcopenia, osteopenia or the combination compared with controls [14]. In a study of 68 pre-frail adults, osteosarcopenic individuals showed a significant reduction in physical performance compared with sarcopenic and osteopenic/osteoporotic individuals [17]. A large study of 5544 older men (mean age $=73.7$ years) from the Osteoporotic Fractures in Men study showed that hazard for fracture compared with healthy controls was substantially greater for men with both low bone mineral density (BMD) and sarcopenia (3.8-fold) than for men with only one condition (1.1- to 1.7-fold) [18].

In contrast, a large cohort of community-dwelling men aged $\geq 70$ years with combined osteopenia/osteoporosis and sarcopenia did not have an increased risk falls and fracture compared with those with either condition alone [19]. In a recent analysis, participants of the Women's Health Initiative (WHI) were classified into mutually exclusive groups based on BMD and sarcopenia status [20]. Whereas low BMD was associated with increased risk of hip fracture, women with sarcopenia alone were at similar risk of hip fracture to non-sarcopenic women with normal BMD, suggesting that sarcopenia alone was not predictive of this outcome. In a further WHI study, appendicular lean mass was predictive of incident hip fracture amongst 872 participants aged 65 years or older who met Fried's criteria for frailty, but this association did not remain statistically significant after adjusting for total hip BMD [21]. These findings are consistent with those of a study of 5911 older men and women in whom sarcopenia, was not associated with incident fractures or falls after adjustment for femoral neck BMD [22]. The disparate findings from these various studies may be in part related to the definitions used for osteoporosis and sarcopenia, but these observations do lead to the question of whether sarcopenia yields any information on fracture risk additional to that obtained from BMD.

Recent studies identifying the co-existence of impaired bone health (osteopenia/osteoporosis), reduced muscle mass or strength (sarcopenia), and increased obesity in middleaged and older women, have led to the proposal of "osteosarcopenic obesity" as a distinct entity [3]. In this classification, osteosarcopenic obesity is described as the most advanced stage in a conceptual model of bone, muscle, and fat tissues in healthy and disease states resulting from aging, or individual comorbidities [23]. Each component of osteosarcopenic obesity occurs frequently with increasing age, and with shared risk factors; thus, an overlap in prevalence is not surprising. However, whether the concurrent existence of sarcopenia, osteoporosis and obesity leads to an increased risk of adverse outcomes including mortality above and beyond the risks associated with the sum of the component parts remains to be proven and is a question of research interest. In this article we critically review evidence for the existence of osteosarcopenic obesity, including definition, prevalence, pathophysiology, outcomes and exploratory approaches to the management of components.

\section{Methods}

Articles included in this narrative, critical literature review were identified through literature searches of PubMed, Scopus, and Embase using the following MeSH items or free words: "osteoporosis", "sarcopenia", "obesity" "osteosarcopenia", "osteosarcopenic obesity"; additional terms searched for in either the title, abstract or keywords included: "definition", "epidemiology", "pathophysiology", "hormones", "exercise", "nutrition", "non-pharmacological", "pharmacological". The search strategy was limited to studies conducted in humans, publications in English language, and full-length articles published from inception until January 15, 2018. Finally, the methodological sections and reference lists of relevant articles (particularly review articles) were scrutinised (by JB, EMD, RF, JMK, FL, SM, SP, JYR, PS) for potentially interesting articles. The process for literature identification and selection of the final number of references included in this paper is outlined in Fig. 1. 


\begin{tabular}{|c|c|c|c|c|c|c|c|}
\hline \multirow[b]{2}{*}{$\begin{array}{l}\text { Presentation } 1 \\
\text { Interactions } \\
\text { between bone, } \\
\text { muscle and fat tissue }\end{array}$} & \multirow[b]{2}{*}{$\begin{array}{l}\text { Presentation } 2 \\
\text { Hormonal aspects of } \\
\text { OSO }\end{array}$} & \multicolumn{4}{|c|}{$\begin{array}{r}\text { Search on PubMed, Scopus and Embase until January 15, } 2018 \\
\text { Mesh terms searched: osteoporosis, sarcopenia, obesity, osteosarcopenia, } \\
\text { osteosarcopenic obesity } \\
\text { Additional terms searched in either title, abstract or keywords: definition, } \\
\text { pathophysiology, epidemiology, exercise, hormones, nutrition, measurement, } \\
\text { non-pharmacological, pharmacological }\end{array}$} & \multirow[b]{2}{*}{$\begin{array}{l}\text { Presentation } 7 \\
\text { Pharmacological } \\
\text { management of } \\
\text { sarcopenia }\end{array}$} & \multirow[b]{2}{*}{$\begin{array}{l}\text { Presentation } 8 \\
\text { Pharmacological and } \\
\text { non-pharmacological } \\
\text { management of OSO }\end{array}$} \\
\hline & & $\begin{array}{l}\text { Presentation } 3 \\
\text { OSO definition and } \\
\text { clinical aspects }\end{array}$ & $\begin{array}{l}\text { Presentation } 4 \\
\text { OSO epidemiology } \\
\text { and consequences }\end{array}$ & $\begin{array}{l}\text { Presentation } \mathbf{5} \\
\text { Role of nutrition in } \\
\text { the development of } \\
\text { OSO }\end{array}$ & $\begin{array}{l}\text { Presentation } 6 \\
\text { Methods to assess } \\
\text { and explore OSO }\end{array}$ & & \\
\hline & & \multicolumn{4}{|c|}{$\begin{array}{l}\text { Total number of relevant references identified through literature review and } \\
\text { manual search of relevant references } \\
\text { (inclusion/exclusion of references was based on the topics of the presentations and } \\
\text { the objectives of the future paper) } \\
\qquad n=103\end{array}$} & & \\
\hline & & \multicolumn{4}{|c|}{$\begin{array}{l}\text { Face-to-face meeting, discussion, additional references identified through } \\
\text { expertise of the ESCEO working group members } \\
\text { Additional references } n=35\end{array}$} & & \\
\hline & & \multicolumn{4}{|c|}{$\begin{array}{l}\text { Total number of relevant references selected by the experts of the ESCEO working } \\
\text { group to be included in the first draft paper } \\
\qquad n=138\end{array}$} & & \\
\hline & & \multicolumn{4}{|c|}{$\begin{array}{l}\text { Review of the first draft of the paper by all the members of the ESCEO working } \\
\text { group. Number of references still present in the paper after this first review } \\
\text { (inclusion/exclusion of references was based on experts' expertise, selection of the } \\
\text { most relevant references according to the objectives of the paper and new } \\
\text { directions of the paper after the first round of review) } \\
n=121\end{array}$} & & \\
\hline & & \multicolumn{4}{|c|}{$\begin{array}{l}\text { Additional references identified to address peer-review comments } n=8 \\
\qquad \begin{array}{l}\text { Final number of references included } \\
n=129\end{array}\end{array}$} & & \\
\hline
\end{tabular}

Fig. 1 Literature selection process. OSO, osteosarcopenic obesity

\section{Epidemiology}

A few studies have appeared in the literature reporting on the epidemiology of osteosarcopenic obesity. However, without a standardised definition of osteosarcopenic obesity it is difficult to make comparisons and draw conclusions on prevalence of as the published studies use multiple definitions for the osteosarcopenic obesity components (Table 1) [24-26].

\section{Definitions}

\section{Obesity}

Overweight and obesity are defined as abnormal or excessive fat accumulation that presents a risk to health. Body mass index (BMI) provides a crude measure of obesity—defined as a person's weight (in kilograms) divided by the square of his/her height in metres; the World Health Organization (WHO) defines obesity in a person with a BMI of $\geq 30 \mathrm{~kg} /$ $\mathrm{m}^{2}$, while a person with a BMI $\geq 25 \mathrm{~kg} / \mathrm{m}^{2}$ and $<30 \mathrm{~kg} / \mathrm{m}^{2}$ is

Table 1 Multiple definitions of osteosarcopenic obesity components used in clinical studies

\begin{tabular}{|c|c|c|c|}
\hline Study & Osteopenia/osteoporosis & Sarcopenia & Obesity \\
\hline Szlejf et al. [24] & At least one $T$-score $\leq-1$ & $\begin{array}{l}\text { FNIH criteria: } \mathrm{ALM}_{\mathrm{BMI}}<0.512 \text { and grip } \\
\text { strength }<16 \mathrm{~kg} \text { in women }\end{array}$ & $\begin{array}{l}\text { Fat mass: } 35 \% \text { body fat if }<60 \text { years; } 40 \% \text { if } \\
>60 \text { years (females) }\end{array}$ \\
\hline Chung et al. [25] & At least one $T$-score $\leq-1$ & $\begin{array}{l}\mathrm{ALM} / \mathrm{ht}^{2}<2 \text { SD below sex-specific young adult } \\
\text { mean }\end{array}$ & Fat mass $>30 \%$ in males or $>40 \%$ in females \\
\hline Ilich et al. [26] & At least one $T$-score $\leq-1$ & ALM residual value of $<1.43(20 \%)$ & Fat mass $\geq 35 \%$ (females) \\
\hline
\end{tabular}

$A L M$ appendicular lean mass, $A L M / h t^{2}$ appendicular lean mass index normalised for height, $F N I H$ Foundation for the National Institutes of Health, $S D$ standard deviation 
considered as overweight [27]. An alternative definition of obesity based on body fat percentage is not well established and has arbitrary cut-off points [28]: the WHO proposes $\geq 35 \%$ body fat for women $<60$ years [29] and $>40 \%$ body fat for women aged $\geq 60$ years and older [30].

\section{Sarcopenia}

Currently, there is no international consensus on the operational definition of sarcopenia, and several definitions of sarcopenia are used with consequent impact on the prevalence of sarcopenia [6, 31-34]. For example, a study of 445 community-dwelling seniors (mean age 71 years, $45 \%$ men) examined the prevalence of sarcopenia using seven available definitions of sarcopenia plus two related definitions. The prevalence of sarcopenia varied between 2.5 and 27.2\% among women, and 3.1 and $20.4 \%$ among men [33].

The European Working Group on Sarcopenia in Older People (EWGSOP) is one of the most widely used conceptual and operational definitions of sarcopenia [6] but different cut-off points were recommended for diagnosis for muscle mass, muscle strength and gait speed. In a sample of hospital referees aged $\geq 65$ years the prevalence of sarcopenia varied two-fold from $9 \%$ to $18 \%$ depending on the cut-offs applied [35]. Thus, the basis for defining variants of sarcopenia are based on questionable foundations.

Recently, the EWGSOP2 has published a revised European consensus on the definition and diagnosis of sarcopenia to delineate clear criteria and tools that define and characterize sarcopenia in clinical practice and research populations. The EWGSOP2 guidelines focus on low muscle strength as the primary parameter to detect sarcopenia; the diagnosis is confirmed by the presence of low muscle quantity or quality, and when all three qualities are detected sarcopenia is considered as severe. In addition, the EWGSOP2 provides clear cut-off points for measurements of variables that identify and characterize sarcopenia [7].

\section{Osteoporosis}

Notably, the definitions employed for the bone component of osteosarcopenic obesity have included both osteopenia and osteoporosis, and consequently may capture a very large proportion of the population of women aged over 50 years. In Sweden, for example, the prevalence of osteopenia is approximately $70 \%$ of women aged $\geq 50$ years, whereas the prevalence of osteoporosis is $21 \%$ [12]. Osteopenia is measured using BMD and based on the lowest $T$-score of the posteroanterior spine, femoral neck, trochanter, or total hip ( $T$-score between 1.0 and 2.5 standard deviations [SD] below the mean adult value) [36]. Osteoporosis is measured as the $T$-score for BMD assessed at the femoral neck (reference site) and defined as BMD 2.5 SD or more below the mean adult value [36, 37].

\section{Diagnostic Techniques}

Dual-energy X-ray absorptiometry (DXA) is commonly used in clinical practice and epidemiological studies to assess body composition, in terms of bone, non-fat mass and fat mass (Table 2). Regional bone density is measured using DXA of the lumbar spine, femoral neck or total hip. Muscle mass is determined from DXA whole body scan which estimates lean mass (i.e. muscle, water, fibrous tissue and viscera) $[6,31,32]$. The composite Short Physical Performance Battery (SPPB) is the most widely used test of overall physical performance $[23,38]$. Other techniques employed for exploration of the pathophysiology of the interactions between bone, muscle and fat include bioelectric impedance analysis (BIA) and magnetic resonance imaging (MRI). MRI and computed tomography are used experimentally to assess muscle fat infiltration, which may be important when considering osteosarcopenic obesity. Anthropometric measurements (e.g. mid-upper arm circumference) may be used to assess obesity, but have suboptimal correlation with other methods.

\section{Reported Prevalence of Osteosarcopenic Obesity}

Given the heterogeneous approach to the definitions of sarcopenia, osteosarcopenia and obesity, defining the prevalence of osteosarcopenic obesity is problematic. A prevalence of $12-19 \%$ of osteosarcopenic obesity has been reported in women aged over 50 years [24-26]. A Mexican study of women aged $\geq 50$ years $(N=434)$ found a prevalence of $19 \%$ and osteosarcopenic obesity was associated with frailty and poor physical performance [24]. Another study among postmenopausal women of mean age 63 years found a prevalence of osteosarcopenic obesity of $12.1 \%$ and an association with poorer functionality in women

Table 2 Methods to assess osteosarcopenic obesity components

\begin{tabular}{lll}
\hline & Primary measure & Secondary measure \\
\hline $\begin{array}{l}\text { Osteopenia/osteo- } \\
\text { porosis }\end{array}$ & DXA & \\
Sarcopenia & DXA & BIA \\
& Grip strength & SPPB \\
& Gait speed & \\
Obesity & DXA & BMI \\
& & Waist circumference \\
& & BIA \\
\hline
\end{tabular}

$B I A$ bioelectric impedance analysis, $B M I$ body mass index, $D X A$ dualenergy X-ray absorptiometry, $S P P B$ short physical performance battery 
presenting with osteosarcopenic obesity, particularly compared to obese women, increasing the risk for bone fractures and immobility due to the combined decline in bone and muscle mass, and increased fat mass [26]. Investigation of the Korean National Health and Nutrition Examination Survey (including $N=3385$ men and $N=4064$ women aged $>50$ years) found the incidence of sarcopenia, sarcopenic obesity, and osteosarcopenic obesity as $31.5 \%, 5.1 \%$, and $4.1 \%$, respectively. Sarcopenic obesity was associated with increased odds for the development of osteoporosis among the middle-aged and older-aged Korean population [25].

Obesity at a young age may also contribute to the early development of osteosarcopenic obesity and frailty sooner than that which occurs in a lean population. Overweight/ obese but otherwise healthy young adults (aged 18-21 years) exhibit 'osteosarcopenic elements' including: increased fat mass, and decreased muscle and bone mass compared with lean controls [39].

\section{Pathophysiology}

Recent evidence suggests a potential interconnection between osteoporosis, sarcopenia, and obesity with shared pathophysiology [40]. The changes in body composition that occur over a lifetime, and interplay between mechanisms leads to progressive losses of bone and muscle mass and an increase in adipose tissue (Fig. 2) [40]. An increase in total and/or abdominal adipose tissue causes an increase in proinflammatory cytokines, as well as hormonal disturbances leading to losses of both muscle and bone tissues through a variety of mechanisms which ultimately affect clinical outcomes, such as an increase in risk for falls and fractures [40].

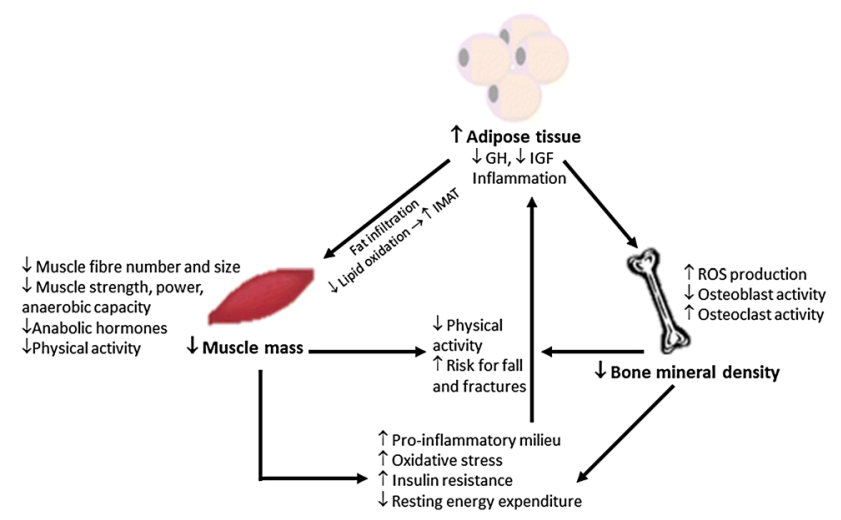

Fig. 2 The interplay between bone, muscle and adipose tissue. GH, growth hormone; IMAT, intramuscular adipose tissue; IGF, insulinlike growth factor; ROS, reactive oxygen species. Reproduced from: Ormsbee MJ et al. Osteosarcopenic obesity: the role of bone, muscle and fat on health. J Cachexia Sarcopenia Muscle (2014) 5:183-192. Reproduction permitted under the terms of the Creative Commons Attribution-NonCommercial License
Bone and muscle are physically and functionally coupled. Several age-related alterations of bone microenvironment and an altered bone-muscle cross-talk are proposed to be relevant contributors to loss of bone strength and mass characteristic of osteoporosis [41]. Insulin-like growth factor-I (IGF-I), myostatin, and cytokines (e.g., interleukin-6 [IL6]), collectively referred to as myokines, are released from skeletal myocytes and exert actions on the muscle and the bone. Analogously, osteokines, including osteocalcin, osteoprotegerin and bone matrix proteins are released from bone cells and participate in the regulation of musculoskeletal homeostasis [41].

The reductions in muscle and bone tissues are associated with decreases in physical activity; once losses hit a threshold, physical activity becomes even more limited leading to a vicious cycle of progressive loss of muscle and bone as well as gain in fat [40]. While age-related changes may be considered of primary importance, other important factors may include endocrine disorders, inadequate nutrition, inflammation, neurodegenerative disorders, physical inactivity, and other chronic and lifestyle factors [42].

\section{Hormonal Aspects}

There are cumulative hormonal changes that occur with aging and obesity, such as a substantial decrease in levels of the main anabolic hormones. Hormonal players that are identified as having a potential role in development of the components of osteosarcopenic obesity are listed in Table 3 [42]. Changes in anabolic hormones have been associated with unfavourable changes in muscle mass, muscle function and impaired functional capacity. Testosterone has a dose-dependent impact on fat-free mass in both the young and old, with higher levels associated with reduction in fat mass and increase in skeletal muscle mass and strength [43]. Low levels of testosterone, but not oestradiol, predict frailty in older men and are associated with incident falls [44-46].

Non-androgenic anabolic hormones predict the risk of frailty in aging men, including IGF-I, dehydroepiandrosterone, parathyroid hormone, and 25-OH vitamin D [47]. Age-related decreases of serum levels of adrenal androgens are shown in healthy men and women [48, 49]. Higher levels of cortisol are detected in frail older women, with blunted diurnal variation in cortisol levels compared with non-frail individuals [50]. Increasing age is also shown to influence 24-h integrated concentration of growth hormone in normal individuals [51].

Increasing age and obesity both contribute to sarcopenia, for which a postulated mechanism involves disturbed insulin signalling and insulin resistance [9]. Frailty and sarcopenia are newly emerging and high impact complications of diabetes [52]. Both diabetes and obesity impact on muscle loss [52], and muscle mass is inversely associated with insulin 
Table 3 Hormonal players identified with a potential role in the development of osteosarcopenic obesity components

\begin{tabular}{ll}
\hline Hormone class & Examples \\
\hline Anabolic & Somatotropic axis, sex steroids \\
Adrenal cortex & Cortisol, adrenal androgens \\
Insulin & TNF- $\alpha$, IL-6, adiponectin, BMPs, IL-13, IL-15, IL-10, leptin, resistin, \\
Adipokines & chimerin, myostatin \\
Myokines & Myostatin, irisin, BMPs, FGF-21, IL-10, MCP-1, TNF- $\alpha$, IL-6, IL-1 $\beta$, IGF-I \\
\hline
\end{tabular}

$B M P$ bone morphogenetic protein, $F G F$ fibroblast growth factor $I G F-I$ insulin-like growth factor, $I L$ interleukin, $M C P-1$ monocyte chemoattractant protein-1, TNF- $\alpha$ tumour necrosis factor- $\alpha$ resistance and prediabetes [53]. Hyperglycaemia predicts persistently lower muscle strength with aging [54], and an excessive loss of skeletal muscle mass has been detected in older adults with type 2 diabetes [55]. In the obese state, dysregulation of adipokines that contribute to muscle maintenance in the lean state leads to sarcopenia [9].

Mechanisms responsible for the development of osteosarcopenic obesity components are complex and may include multiple factors: endocrine versus local regulation, threshold effects, hormonal implications of comorbidities, and cross-talk between endocrine-immune-neurologic factors. Bidirectional interactions between hormonal changes and altered body composition are identified but uncertainties remain as to causalities versus reverse causalities, and bidirectional interactions create conditions for self-amplifying vicious circles. While many potential and biologically plausible contributing mechanisms are postulated, indicating a likely multifactorial pathogenesis, biologically plausible hypotheses have not yet established a clinical relevance for pathophysiology, prevention, or treatment. Furthermore, there is a need for unravelling of the complex 'local' fatmuscle-immune system interactions and their interaction with systemic hormones and neurogenic factors.

\section{Nutritional Aspects}

The role of nutrition in the development of osteosarcopenic obesity components is significant. Middle-aged and older women who eat a healthy diet are less likely to have multiple body composition abnormalities [56]. The typical Western diet and lifestyle promotes several chronic diseases including the components of osteosarcopenic obesity, by facilitating a pro-inflammatory state, largely via the imbalance in omega-6/omega-3 polyunsaturated fatty acid (PUFA) ratio and low-fibre and high-processed food consumption [57], which is linked to a higher risk of frailty and fractures [58, 59]. A Western pattern diet is linked to a higher risk of sarcopenia in menopausal women as compared with a Mediterranean pattern diet (high in low-fat dairy, vegetable, fish, nut, olive and vegetable oil), which is associated with lower risk [60]. Greater adherence to a Mediterranean pattern diet is associated with less loss of skeletal muscle mass and lean body mass, better physical performance [61], a significant reduction in waist circumference [62], and a lower incidence of frailty [63].

Deficiencies in macronutrients are important, specifically protein and amino acid intake (in particular the branched amino acids) in terms of quantity, quality (type of protein, essential amino acids, and absorption rate) and timing of intake. Energy imbalances in aging, excessive high glycaemic carbohydrate, lower protein intakes and low long-chain PUFA intakes may contribute to the components of osteosarcopenic obesity [64]. Dietary protein intake contributes to maintenance of lean muscle mass and may be a modifiable risk factor for sarcopenia in older adults [65]. Protein intakes of $\geq 1.0 \mathrm{~g} / \mathrm{kg}$ body weight/day may be optimal for maintaining lean mass and physical function in older adults [66].

Deficiencies in multiple micronutrients may be important in osteosarcopenic obesity, in terms of intake, absorption, and bioavailability [67]. Obese adults are shown to have lower micronutrient intake and higher prevalence of micronutrient inadequacy as compared with normal weight adults [68]. Low serum vitamin D level in mid- and later-life is associated with multiple indices of adverse body composition [69].

Summarizing the above, it has to be acknowledged that very few studies have specifically addressed nutritional intake in the context of osteosarcopenic obesity. Most of the presented information has been derived from studies that focused separately on sarcopenia, osteoporosis or obesity.

\section{Health Outcomes}

Although understanding of the aetiology, prevalence, and consequences of osteosarcopenic obesity components are, so far, limited, it is reasonable to infer a negative impact in an aging, and increasingly obese population. The potential clinical consequences of osteosarcopenic obesity are linked to each of the underlying conditions, with the possibility of interaction to increase further the adverse health effects. Clinical outcomes associated with osteosarcopenic obesity 
components include: increased risk of fractures, impaired functional status (including activities of daily living) [70, 71], physical disability, insulin resistance, increased risk of infections, increased length of hospital stay, and reduced survival [40]. However, there is little evidence to date on an additive or multiplicative health impact of osteoporosis in a distinct overlap with obesity and sarcopenia. The cascade of metabolic abnormalities associated with changes in body composition related to osteosarcopenic obesity components may also be important in younger populations with comorbidities such as diabetes mellitus, glucocorticoid use, or malignancy.

Frailty is a geriatric syndrome resulting from age-related declines across multiple physiological systems leading to increased risk of falls, hospitalisation, institutionalisation and mortality [72, 73]. Frailty and sarcopenia overlap in terms of physical factors [74], and osteoporosis is linked to frailty [75]. The link between obesity and frailty is less clear and complex. Osteosarcopenic obesity components occur frequently in middle-aged and older women and are independently associated with frailty and poor physical performance; women with osteosarcopenic obesity have lower functional abilities and higher frailty scores compared with their counterparts without osteosarcopenic obesity [24].

\section{Body Fat Location: Distinguishing Between Visceral and Subcutaneous Adipose Tissue}

The location of body fat may have differential impact upon health outcomes. Abdominal obesity is more closely associated with incidence of frailty than general obesity in older people [76]. Among a sample population of older people $(N=801)$, the prevalence of osteosarcopenic obesity was determined as $6.8 \%$; subjects with a visceral/subcutaneous adipose tissue ratio $>1$ were classified as having visceral obesity, and subjects with values under 1 were classified as having subcutaneous obesity [77]. Visceral obesity was closely linked to a higher risk of fractures and inflammation [77].

\section{Management of Osteosarcopenic Obesity Components}

No clinical studies are currently available that have tested therapeutic approaches in individuals with osteosarcopenic obesity. The components of osteosarcopenic obesity occur as a result of sedentary behaviour and a lack of regular physical activity, among other factors. Consequently, the therapeutic approach should include a combination of tailored exercise, optimised nutrition, and pharmacotherapy targeted at the three components.

\section{Exercise}

Multidimensional treatment protocols should include a programme of multimodal exercise comprising the elements of balance, aerobic and resistance exercise. Mobility-limited older individuals have a distinct muscle phenotype of poor muscle quality and intermuscular fat accumulation. The rise in intermuscular fat found in sarcopenia may be suppressed by physical activity [78]; mobility-limited older people have a greater change in intermuscular adipose tissue over time [8]. Moderate-intensity physical activity programmes significantly improve physical functioning in mobility-limited older adults, attenuate intermuscular fat accumulation and improve muscle quality. A lifestyle intervention study of aerobic and resistance exercise versus health education in older people (aged 70-89 years) resulted in a positive improvement in physical activity (SPPB) over an average of 2.7 years follow-up [79]. A study of the effects of a 12-week program of resistance training in older women $(N=62$, mean age 68 years; mean BMI $27 \mathrm{~kg} / \mathrm{m}^{2}$ ) found that performing 3 sets of each exercise 3-times weekly has beneficial effects on the risk factors for osteosarcopenic obesity including skeletal muscle mass and strength. Moreover, moderate-intense physical exercise is an important stimulus for osteoporosis prevention and treatment [80].

\section{Nutrition}

Nutritional interventions to prevent and/or alleviate osteosarcopenic obesity components include: adequate intake of protein ( $>0.8 \mathrm{~g} / \mathrm{kg} /$ day), calcium $(1200 \mathrm{mg} /$ day $)$, magnesium (320 mg/day), and vitamin D (800 IU/day), and increasing consumption of foods containing omega-3 PUFAs ( $1 \mathrm{~g} /$ day) and fibre ( $25 \mathrm{~g} /$ day for women) [57, 81]. There is evidence for a higher protein requirement in older people (1.0-1.2 g/ $\mathrm{kg} /$ day), due to a blunted muscle protein synthetic response to protein ingestion, and higher protein intake is recommended in those who are exercising $(\geq 1.2 \mathrm{~g} / \mathrm{kg} /$ day) and in older adults with acute or chronic diseases (1.2-1.5 g/ $\mathrm{kg} /$ day) [81-83]. Dietary protein quality is also important. Leucine supplementation enhances myofibrillar protein synthesis in older men consuming lower- and higher-protein diets with and without exercise [84]. Increased protein intake $(>0.8 \mathrm{~g} / \mathrm{kg} /$ day) is known to increase BMD in older people with osteoporosis [81, 85].

Vitamin D deficiency is associated with osteosarcopenic obesity components $[69,86]$. The combined intervention of a vitamin D with high whey protein, leucine-enriched oral supplement has resulted in improvements in muscle mass and lower-extremity function as well as in a decrease in fat mass among sarcopenic older adults [87, 88]. Omega-3 PUFAs may influence skeletal muscle health and function [89], and correlations are found between omega-3 and 
omega-6 PUFAs, protein intake, BMD and physical performance [90]. Omega-3 PUFA supplementation increases the rate of muscle protein synthesis in older adults [91].

It is as yet unclear how high protein diets impact on body weight, and how dietary intervention can improve bone, muscle and fat all together, for which further studies are warranted.

\section{Combined Exercise and Nutrition}

Older adults who exhibit osteosarcopenic obesity components may benefit from combined efforts to improve diet (as specified above) and physical activity involving aerobic, strength, flexibility and balance training, which requires further investigation [57]. Together these can positively influence intermuscular fat accumulation and improve muscle quality with equivocal effects on physical functioning. Supplementation with whey protein, essential amino acids and vitamin $\mathrm{D}$, in conjunction with age-appropriate exercise, is shown to increase fat-free mass and strength, and boost nutritional status, physical function and quality of life in sarcopenic older persons (mean age 80 years) with only a 12-week program [92]. In the VIVE-2 study a combination of exercise intervention ( 3 times per week for 6 months) and nutritional supplementation with whey protein $(20 \mathrm{~g})$, vitamin D (800 IU), calcium, vitamins and minerals (150 kcal) among people aged $70+$ years, led to an increase in muscle density and a reduction in intermuscular fat [78, 93, 94].

\section{Gut Microbiota}

Increasing evidence suggests a role for altered gut microbiota on inflammation, obesity, and other chronic conditions. A connection between osteosarcopenic obesity components concurrent with altered microbiota in older individuals, particularly those living in long-term care facilities, has been established [95]. The gut microbiota may be a new therapeutic target in muscle wasting [96]. The gut microbiota can modulate amino acid availability; antibiotics have been shown to increase levels of circulating amino acids, which would have been otherwise degraded by intestinal bacteria [97].

\section{Pharmacotherapy}

Research interests have focused on pharmacological agents to separately address the three components of osteosarcopenic obesity. Medications available to reduce obesity have limited effects and are yet to be properly tested in older people [98, 99]. Drugs available for the prevention and treatment of osteoporosis impact upon BMD and fracture risk, although their effect on muscle or fat mass is not well studied [100,101]. Multiple pathways are involved in the loss of muscle mass arising from aging, malnutrition, obesity, inflammation and inactivity, which offers many targets for therapeutic intervention [102].

Several pharmacological agents are currently under investigation to manage sarcopenia e.g., testosterone, selective androgen receptor modulators (SARMs), AMP-activated protein kinase (AMPK) agonists, activin 11R antagonists, growth hormone, IGF-I analogues, and ghrelin-modulating agents [103]. Targeting pathways that centrally regulate both bone and muscle (e.g. growth hormone, IGF-I, sex steroids), and newly emerging pathways that facilitate communications between these two tissues (e.g. activin/myostatin) might allow a greater therapeutic benefit in frail older people [104]. To aid future development of new therapeutic targets for sarcopenia, recommendations for the conduct of clinical trials have been developed, along with the proposal for a core outcome set to include the domains of activity/independence, quality of life, costs, and muscle mass, strength and performance $[105,106]$.

\section{Testosterone}

Pharmacological treatment effects with anabolic hormones can be demonstrated but are rather mitigated and of uncertain clinical significance alongside some safety concerns. Several trials conducted with testosterone show a direct effect on muscle mass and, in several cases, on muscle strength and performance, with a slight reduction in body fat, and some effect on bone density [107-110]. Testosterone supplementation is also shown to benefit other aspects of health, including sexual function, physical function, vitality, quality of life and improved mood [109, 111]. However, when considering testosterone replacement therapy, the potential benefits of treatment must be weighed against the possible side effects $[112,113]$, and the broad application of testosterone therapy in older men with low testosterone level is not recommended [114].

\section{Selective Androgen Receptor Modulators (SARMs)}

SARMs have the same anabolic effect on muscle tissue as testosterone. These new drugs may expand the clinical application of androgens in sarcopenia as they enter the clinical phase of research, although to date there are few studies. Treatment with ostarine (enobosarm) for 3 months is demonstrated to increase muscle mass and stair climbing power in healthy older men and postmenopausal women [115].

\section{Growth Hormone}

Many studies reported only marginal effects of growth hormone $(\mathrm{GH})$ supplementation on skeletal muscle mass, bone 
density, fat mass and physical function [116]. Most studies have documented that GH supplementation is ineffective in older subjects, by increasing muscle mass but not muscle strength [117-119]. Moreover, the majority of trials conducted on GH supplementation have reported a high incidence of adverse effects [116, 118, 119]. Consequently, GH treatment should not be considered as a safe strategy to improve body composition and functionality in older individuals.

\section{Ghrelin Agonist}

Ghrelin concentrations have been reported to be strongly correlated with the amount of skeletal muscle mass. An enhanced ghrelin blood concentration results in an increased sensation of hunger and food intake. Considering that anorexia and malnutrition are important causes of sarcopenia, it has been hypothesised that ghrelin supplementation could be effective. Very few clinical studies on synthetic ghrelin or ghrelin agonist treatment have been conducted in older subjects. In healthy older adults, without sarcopenia, 2 years of an oral ghrelin mimetic agent (ibutamoren mesylate; MK-0677) increased the GH and IGF-I blood levels and muscle mass but without significant changes in strength or physical function [120]. In other studies of ibutamoren in persons with hip fracture the increase in plasma IGF-I levels was not paralleled by improvement in most functional performance measures, and one trial was terminated early due to a safety signal of congestive heart failure [121, 122].

\section{Myostatin Inhibitors}

Myokines are involved in communication pathways from skeletal muscle to bone [123]. Myostatin (growth differentiation factor-8) is a member of the transforming growth factor $\beta$ (TGF- $\beta$ ) superfamily that is expressed almost exclusively in skeletal muscle. Myostatin inhibits myoblast proliferation and thus acts as a negative regulator of skeletal muscle mass.

At present, limited data is available from human studies of myostatin inhibitors [124]. Bimagrumab increased total thigh muscle volume and appendicular muscle mass in sarcopenic older persons $(N=40)$ [125]. In parallel, decreases in intermuscular thigh adipose tissue of $9.5 \%$ and $3.8 \%$ in subcutaneous thigh fat were measured at 24 weeks [125]. Participants with slower walking speed at baseline receiving bimagrumab had greater improvements in gait speed (mean $0.15 \mathrm{~m} / \mathrm{s}, p=0.009$ ) and 6-min walk distance (mean $82 \mathrm{~m}$; $p=0.022$ ) than those receiving placebo [125]. In addition, bimagrumab improved body composition and insulin sensitivity in insulin-resistant individuals [126]. This initial proof-of-concept data still needs to be confirmed in larger pivotal trials.

\section{Angiotensin-Converting Enzyme (ACE) Inhibitors}

The effects of ACE inhibitors on muscle function have been mainly attributed to positive cardiovascular effects. There is contrasting data from observational studies and RCTs for the effect of ACE inhibition on skeletal muscle. Among 95 participants that completed a 20-week trial, the mean 6-min walking test was significantly improved in subjects receiving perindopril relative to the placebo group (mean betweengroup difference $31 \mathrm{~m}$ ) [127]; while another trial reported no beneficial effect on physical performance in older subjects receiving an ACE inhibitor for 6 months [128]. A combined study of leucine and ACE inhibitors as therapy for sarcopenia (LACE trial) is underway [129].

\section{Discussion}

A review of the current literature shows that while data is accumulating for the existence of osteosarcopenic obesity as a distinct entity a number of questions remain, not least the clinical relevance of identification of such a condition. A progressive loss of bone and muscle mass and increase in adipose tissue occurs with normal aging. Thus, identification of the epidemiological overlap of osteoporosis, sarcopenia, and obesity is perhaps not surprising given the common risk factors and increasing prevalence of these conditions in older age. Evidence for the pathophysiological overlap of these conditions is expanding, which may occur through an interplay of inflammatory and hormonal mechanisms. However, a causal relationship between the osteosarcopenic obesity components is yet to be identified, and more comprehensive research to understand the underlying biological phenomena linking the three conditions is needed.

Whether osteosarcopenic obesity should be distinguished as a distinct condition, separate from osteosarcopenia or sarcopenic obesity remains to be determined. Additional studies should assess whether the clinical outcomes associated with osteosarcopenic obesity are worse than the mere addition of those linked with its components. Consequently, this will help to determine whether defining a person as having this triad will result in better treatment and outcomes than addressing each of the three conditions separately.

In conclusion, we consider that there is insufficient evidence to support a discrete clinical entity of osteosarcopenic obesity at this time. To expand knowledge and understanding in this area, there is a need for consensus on a definition of osteosarcopenic obesity, which will allow for identification, further epidemiological studies and comparisons between studies. A critical first step in this process requires further research to standardise the operational definition of osteosarcopenic obesity components (sarcopenia and obesity). Furthermore, research is needed to confirm or reject the 
hypothesis that the identification of osteosarcopenic obesity adds anything to the concept of osteosarcopenia plus obesity, in terms of clinical outcomes and therapeutic guidelines.

Authors' Contributions The views expressed in this article represent the outcomes of a Working Group jointly organized by the European Society for Clinical and Economic Aspects of Osteoporosis, Osteoarthritis and Musculoskeletal Diseases (ESCEO) and the World Health Organization Collaborating Center for Public Health Aspects of Musculoskeletal Health and Aging, Liège, Belgium, and held in Zurich, Switzerland, on January 16th, 2018. The working group comprised a global representation of clinicians and researchers with different specialties invited for their expertise and knowledge regarding osteoporosis, sarcopenia, and obesity: Jürgen Bauer, Cyrus Cooper, Alfonso Cruz-Jentoft, Roger Fielding, John Kanis, Jean-Yves Reginster, Olivier Bruyère, Matteo Cesari, Roland Chapurlat, Nasser Al-Daghri, Elaine Dennison, Jean-Marc Kaufman, Francesco Landi, Andrea Laslop, Médéa Locquet, Stefania Maggi, Eugene McCloskey, Simone Perna, René Rizzoli, Yves Rolland, Mariangela Rondanelli, Pawel Szulc, Bruno Vellas, and Mila Vlaskovska. Selected members of the working group (JYR, RF, JMK, SM, ED, SP, PW, FL, JB) conducted literature searches and exchanged peer-review publications with the full working group in advance of the meeting, and presented their assessment of the available data to colleagues at the meeting (including: $\mathrm{CC}, \mathrm{ACJ}$, JK, OB, RC, JMK, FL, AL, ML, SM, EMC, SP, RR, YR, PS, BV, $\mathrm{MV})$. Agreement on the principles outlined in this article were based on an exchange of views and discussion of the working group during the 1-day interactive meeting. Following the meeting, members of the writing group (JB, RF, JK, CC, ACJ, JYR) prepared a first draft of this manuscript, which was circulated to all working group members for review and input, including those who had been unable to attend the meeting (MC, NAD, MR). Following two rounds of review and comment from all 24 working group members, the final manuscript was submitted. All authors meet the ICMJE criteria for authorship for this manuscript, take responsibility for the integrity of the work as a whole, and have given final approval to the version to be published.

Funding The meeting was funded by the ESCEO, a Belgian not-forprofit organisation. The authors thank the Chair for Biomarkers of Chronic Diseases and the International Scientific Partnership Program (ISPP\#0111) at King Saud University, Riyadh, Saudi Arabia for their support. Editorial assistance in the preparation of this manuscript was provided by Lisa Buttle, $\mathrm{PhD}$, of Medscript Ltd., which was funded by the ESCEO asbl, Belgium.

Conflict of interest $\mathrm{J}$ Bauer reports grants and personal fees from Nestlé, Danone Nutricia, personal fees from Pfizer, Novartis, and Bayer, outside of the submitted work. A.J. Cruz-Jentoft reports personal fees for lecture or advisory boards from Abbott Nutrition, Nutricia, Nestlé, Pfizer and Regeneron, outside of the submitted work. R. Fielding reports grants from the National Institutes of Health (National Institute on Aging), during the conduct of the study; grants, personal fees and other from Axcella Health; other from Inside Tracker; grants and personal fees from Biophytis; grants and personal fees from Astellas; personal fees from Cytokinetics; personal fees from Amazentis; grants and personal fees from Nestlé, and personal fees from GSK, outside of the submitted work. J. Kanis reports grants from Amgen, grants from Lilly, grants from Radius Health, grants from UCB, other from Meda, outside the submitted work. O. Bruyere reports grants from Biophytis, IBSA, Meda, Servier, SMB, and Theramex, outside of the submitted work. M. Cesari reports personal fees for lecture or advisory boards from Nestlé, Pharma 4D and Pluristem, outside of the submitted work. E. Dennison reports personal fees for lectures or ad- visory boards from UCB and Pfizer, outside of the submitted work. S. Maggi reports grants from Takeda, MSD, GSK, and Pfizer outside of the submitted work. E. McCloskey reports personal fees for lectures/ advisory board and/or research funding from AgNovos, Amgen, Consilient Healthcare, Internis, Lilly, Radius Health, Redx Oncology Ltd, Roche, and UCB, outside of the submitted work. R. Rizzoli reports personal fees for lecture or advisory boards from Radius Health, Sandoz, Effryx, Nestlé, Danone, Mylan, CNIEL, outside of the submitted work. C. Cooper reports personal fees from Alliance for Better Bone Health, Amgen, Eli Lilly, GSK, Medtronic, Merck, Novartis, Pfizer, Roche, Servier, Takeda and UCB, outside of the submitted work. J-Y. Reginster, N. Al-Daghri, A. Laslop, M. Locquet, M. Vlaskovska, S. Perna, Y. Rolland, M. Rondanelli, P. Szulc, R. Chapurlat, F. Landi, B. Vellas and J.M. Kaufman report nothing to disclose.

Open Access This article is distributed under the terms of the Creative Commons Attribution 4.0 International License (http://creativeco mmons.org/licenses/by/4.0/), which permits unrestricted use, distribution, and reproduction in any medium, provided you give appropriate credit to the original author(s) and the source, provide a link to the Creative Commons license, and indicate if changes were made.

\section{References}

1. von Ruesten A, Steffen A, Floegel A, van der Daphne A, Masala G, Tjonneland A, Halkjaer J, Palli D, Wareham NJ, Loos RJ, Sorensen TI, Boeing H (2011) Trend in obesity prevalence in European adult cohort populations during follow-up since 1996 and their predictions to 2015. PLoS ONE 6(11):e27455. https:// doi.org/10.1371/journal.pone.0027455

2. Mathus-Vliegen EM (2012) Prevalence, pathophysiology, health consequences and treatment options of obesity in the elderly: a guideline. Obes Facts 5(3):460-483. https://doi. org/10.1159/000341193

3. Ilich JZ (2017) Another impairment in older age: what does osteosarcopenic obesity syndrome mean for middle-aged and older women? J Am Med Dir Assoc 18(8):648-650. https://doi. org/10.1016/j.jamda.2017.05.001

4. Davison MJ, Maly MR, Adachi JD, Noseworthy MD, Beattie KA (2017) Relationships between fatty infiltration in the thigh and calf in women with knee osteoarthritis. Aging Clin Exp Res 29(2):291-299. https://doi.org/10.1007/s40520-016-0556-Z

5. Barazzoni R, Bischoff SC, Boirie Y, Busetto L, Cederholm T, Dicker D, Toplak H, Van Gossum A, Yumuk V, Vettor R (2018) Sarcopenic obesity: time to meet the challenge. Clin Nutr. https ://doi.org/10.1016/j.clnu.2018.04.018

6. Cruz-Jentoft AJ, Baeyens JP, Bauer JM, Boirie Y, Cederholm T, Landi F, Martin FC, Michel JP, Rolland Y, Schneider SM, Topinkova E, Vandewoude M, Zamboni M, European Working Group on Sarcopenia in Older P (2010) Sarcopenia: European consensus on definition and diagnosis: report of the european working group on sarcopenia in older people. Age Ageing 39(4):412-423. https://doi.org/10.1093/ageing/afq034

7. Cruz-Jentoft AJ, Bahat G, Bauer J, Boirie Y, Bruyere O, Cederholm T, Cooper C, Landi F, Rolland Y, Sayer AA, Schneider SM, Sieber CC, Topinkova E, Vandewoude M, Visser M, Zamboni M (2018) Sarcopenia: revised European consensus on definition and diagnosis. Age Ageing. https://doi.org/10.1093/ageing/afy169

8. Reid KF, Doros G, Clark DJ, Patten C, Carabello RJ, Cloutier GJ, Phillips EM, Krivickas LS, Frontera WR, Fielding RA (2012) Muscle power failure in mobility-limited older adults: preserved single fiber function despite lower whole muscle size, 
quality and rate of neuromuscular activation. Eur J Appl Physiol 112(6):2289-2301. https://doi.org/10.1007/s00421-011-2200-0

9. Kalinkovich A, Livshits G (2017) Sarcopenic obesity or obese sarcopenia: a cross talk between age-associated adipose tissue and skeletal muscle inflammation as a main mechanism of the pathogenesis. Ageing Res Rev 35:200-221. https://doi. org/10.1016/j.arr.2016.09.008

10. Marzetti E, Calvani R, Tosato M, Cesari M, Di Bari M, Cherubini A, Collamati A, D’Angelo E, Pahor M, Bernabei R, Landi F (2017) Sarcopenia: an overview. Aging Clin Exp Res 29(1):1117. https://doi.org/10.1007/s40520-016-0704-5

11. Baumgartner RN, Wayne SJ, Waters DL, Janssen I, Gallagher D, Morley JE (2004) Sarcopenic obesity predicts instrumental activities of daily living disability in the elderly. Obes Res 12(12):1995-2004. https://doi.org/10.1038/oby.2004.250

12. Kanis JA, Johnell O, Oden A, Sembo I, Redlund-Johnell I, Dawson A, De Laet C, Jonsson B (2000) Long-term risk of osteoporotic fracture in Malmo. Osteoporos Int 11(8):669-674

13. Hirschfeld HP, Kinsella R, Duque G (2017) Osteosarcopenia: where bone, muscle, and fat collide. Osteoporos Int 28(10):27812790. https://doi.org/10.1007/s00198-017-4151-8

14. Kaplan SJ, Pham TN, Arbabi S, Gross JA, Damodarasamy M, Bentov I, Taitsman LA, Mitchell SH, Reed MJ (2017) Association of radiologic indicators of frailty with 1-year mortality in older trauma patients: opportunistic screening for sarcopenia and osteopenia. JAMA Surg 152(2):e164604. https://doi.org/10.1001/ jamasurg.2016.4604

15. Nielsen BR, Abdulla J, Andersen HE, Schwarz P, Suetta C (2018) Sarcopenia and osteoporosis in older people: a systematic review and meta-analysis. Eur Geriatr Med 9(4):419-434. https://doi. org/10.1007/s41999-018-0079-6

16. Yoo JI, Kim H, Ha YC, Kwon HB, Koo KH (2018) Osteosarcopenia in patients with hip fracture is related with high mortality. J Korean Med Sci 33(4):e27. https://doi.org/10.3346/ jkms.2018.33.e27

17. Drey M, Sieber CC, Bertsch T, Bauer JM, Schmidmaier R (2016) Osteosarcopenia is more than sarcopenia and osteopenia alone. Aging Clin Exp Res 28(5):895-899. https://doi.org/10.1007/ s40520-015-0494-1

18. Chalhoub D, Cawthon PM, Ensrud KE, Stefanick ML, Kado DM, Boudreau R, Greenspan S, Newman AB, Zmuda J, Orwoll ES, Cauley JA (2015) Risk of nonspine fractures in older adults with sarcopenia, low bone mass, or both. J Am Geriatr Soc 63(9):1733-1740. https://doi.org/10.1111/jgs.13605

19. Scott D, Seibel M, Cumming R, Naganathan V, Blyth F, Le Couteur DG, Handelsman DJ, Waite LM, Hirani V (2018) Does combined osteopenia/osteoporosis and sarcopenia confer greater risk of falls and fracture than either condition alone in older men? The Concord health and ageing in men project. J Gerontol A Biol Sci Med Sci. https://doi.org/10.1093/gerona/gly162

20. Harris R, Chang Y, Beavers K, Laddu-Patel D, Bea J, Johnson K, LeBoff M, Womack C, Wallace R, Li W, Crandall C, Cauley $\mathrm{J}$ (2017) Risk of fracture in women with sarcopenia, low bone mass, or both. J Am Geriatr Soc 65(12):2673-2678. https://doi. org/10.1111/jgs. 15050

21. Zaslavsky O, Li W, Going S, Datta M, Snetselaar L, Zelber-Sagi S (2017) Association between body composition and hip fractures in older women with physical frailty. Geriatr Gerontol Int 17(6):898-904. https://doi.org/10.1111/ggi.12798

22. Trajanoska K, Schoufour JD, Darweesh SK, Benz E, MedinaGomez C, Alferink LJ, Lahousse L, Brusselle G, Stricker B, Darwish Murad S, Zillikens MC, Uitterlinden AG, Ikram MA, Franco OH, Rivadeneira F (2018) Sarcopenia and its clinical correlates in the general population: the Rotterdam study. J Bone Miner Res 33(7):1209-1218. https://doi.org/10.1002/jbmr.3416
23. Ilich JZ, Kelly OJ, Inglis JE (2016) Osteosarcopenic obesity syndrome: what is it and how can it be identified and diagnosed? Curr Gerontol Geriatr Res 2016:7325973. https://doi. org/10.1155/2016/7325973

24. Szlejf C, Parra-Rodriguez L, Rosas-Carrasco O (2017) Osteosarcopenic obesity: prevalence and relation with frailty and physical performance in middle-aged and older women. J Am Med Dir Assoc 18(8):733 e731-733 e735. https://doi.org/10.1016/j.jamda .2017 .02 .023

25. Chung JH, Hwang HJ, Shin HY, Han CH (2016) Association between sarcopenic obesity and bone mineral density in middleaged and elderly Korean. Ann Nutr Metab 68(2):77-84. https:// doi.org/10.1159/000442004

26. Ilich JZ, Inglis JE, Kelly OJ, McGee DL (2015) Osteosarcopenic obesity is associated with reduced handgrip strength, walking abilities, and balance in postmenopausal women. Osteoporos Int 26(11):2587-2595. https://doi.org/10.1007/s00198-015-3186-y

27. WHO (2000) World Health Organization. Obesity: preventing and managing the global epidemic. Report of a WHO consultation. World Health Organ Tech Rep Ser 894:1-253

28. Shah NR, Braverman ER (2012) Measuring adiposity in patients: the utility of body mass index (BMI), percent body fat, and leptin. PLoS ONE 7(4):e33308. https://doi.org/10.1371/journ al.pone. 0033308

29. WHO (1995) World health organization. Physical status: the use and interpretation of anthropometry. Report of a WHO expert committee. World Health Organ Tech Rep Ser 854(1):e452

30. Dufour AB, Hannan MT, Murabito JM, Kiel DP, McLean RR (2013) Sarcopenia definitions considering body size and fat mass are associated with mobility limitations: the Framingham study. J Gerontol A Biol Sci Med Sci 68(2):168-174. https://doi. org/10.1093/gerona/gls109

31. Studenski SA, Peters KW, Alley DE, Cawthon PM, McLean RR, Harris TB, Ferrucci L, Guralnik JM, Fragala MS, Kenny AM, Kiel DP, Kritchevsky SB, Shardell MD, Dam TT, Vassileva MT (2014) The FNIH sarcopenia project: rationale, study description, conference recommendations, and final estimates. J Gerontol A Biol Sci Med Sci 69(5):547-558. https://doi.org/10.1093/ gerona/glu010

32. Janssen I, Heymsfield SB, Ross R (2002) Low relative skeletal muscle mass (sarcopenia) in older persons is associated with functional impairment and physical disability. J Am Geriatr Soc 50(5):889-896

33. Bischoff-Ferrari HA, Orav JE, Kanis JA, Rizzoli R, Schlogl M, Staehelin HB, Willett WC, Dawson-Hughes B (2015) Comparative performance of current definitions of sarcopenia against the prospective incidence of falls among community-dwelling seniors age 65 and older. Osteoporos Int 26(12):2793-2802. https ://doi.org/10.1007/s00198-015-3194-y

34. Batsis JA, Barre LK, Mackenzie TA, Pratt SI, Lopez-Jimenez F, Bartels SJ (2013) Variation in the prevalence of sarcopenia and sarcopenic obesity in older adults associated with different research definitions: dual-energy X-ray absorptiometry data from the National Health and Nutrition Examination Survey 19992004. J Am Geriatr Soc 61(6):974-980. https://doi.org/10.1111/ jgs. 12260

35. Beaudart C, Reginster JY, Slomian J, Buckinx F, Locquet M, Bruyere O (2014) Prevalence of sarcopenia: the impact of different diagnostic cut-off limits. J Musculoskelet Neuronal Interact 14(4):425-431

36. Kanis JA, Melton LJ 3rd, Christiansen C, Johnston CC, Khaltaev N (1994) The diagnosis of osteoporosis. J Bone Miner Res 9(8):1137-1141. https://doi.org/10.1002/jbmr.5650090802

37. Kanis JA, McCloskey EV, Johansson H, Oden A, Melton LJ 3rd, Khaltaev N (2008) A reference standard for the description of 
osteoporosis. Bone 42(3):467-475. https://doi.org/10.1016/j. bone.2007.11.001

38. Beaudart C, McCloskey E, Bruyere O, Cesari M, Rolland Y, Rizzoli R, Araujo de Carvalho I, Amuthavalli Thiyagarajan J, Bautmans I, Bertiere MC, Brandi ML, Al-Daghri NM, Burlet N, Cavalier E, Cerreta F, Cherubini A, Fielding R, Gielen E, Landi F, Petermans J, Reginster JY, Visser M, Kanis J, Cooper C (2016) Sarcopenia in daily practice: assessment and management. BMC Geriatr 16(1):170. https://doi.org/10.1186/s12877-016-0349-4

39. Stefanaki C, Peppa M, Boschiero D, Chrousos GP (2016) Healthy overweight/obese youth: early osteosarcopenic obesity features. Eur J Clin Invest 46(9):767-778. https://doi.org/10.1111/ eci. 12659

40. Ormsbee MJ, Prado CM, Ilich JZ, Purcell S, Siervo M, Folsom A, Panton L (2014) Osteosarcopenic obesity: the role of bone, muscle, and fat on health. J Cachexia Sarcopenia Muscle 5(3):183-192. https://doi.org/10.1007/s13539-014-0146-x

41. Picca A, Calvani R, Manes-Gravina E, Spaziani L, Landi F, Bernabei R, Marzetti E (2017) Bone-muscle crosstalk: unraveling new therapeutic targets for osteoporosis. Curr Pharm Des 23(41):6256-6263. https://doi.org/10.2174/138161282366617 0526112300

42. Ilich JZ, Kelly OJ, Inglis JE, Panton LB, Duque G, Ormsbee MJ (2014) Interrelationship among muscle, fat, and bone: connecting the dots on cellular, hormonal, and whole body levels. Ageing Res Rev 15:51-60. https://doi.org/10.1016/j.arr.2014.02.007

43. Bhasin S, Woodhouse L, Casaburi R, Singh AB, Mac RP, Lee M, Yarasheski KE, Sinha-Hikim I, Dzekov C, Dzekov J, Magliano L, Storer TW (2005) Older men are as responsive as young men to the anabolic effects of graded doses of testosterone on the skeletal muscle. J Clin Endocrinol Metab 90(2):678-688. https ://doi.org/10.1210/jc.2004-1184

44. Wu FC, Tajar A, Pye SR, Silman AJ, Finn JD, O'Neill TW, Bartfai G, Casanueva F, Forti G, Giwercman A, Huhtaniemi IT, Kula K, Punab M, Boonen S, Vanderschueren D, European Male Aging Study G (2008) Hypothalamic-pituitary-testicular axis disruptions in older men are differentially linked to age and modifiable risk factors: the European male aging study. J Clin Endocrinol Metab 93(7):2737-2745. https://doi.org/10.1210/ jc.2007-1972

45. Hyde Z, Flicker L, Almeida OP, Hankey GJ, McCaul KA, Chubb SA, Yeap BB (2010) Low free testosterone predicts frailty in older men: the health in men study. J Clin Endocrinol Metab 95(7):3165-3172. https://doi.org/10.1210/jc.2009-2754

46. Vandenput L, Mellstrom D, Laughlin GA, Cawthon PM, Cauley JA, Hoffman AR, Karlsson MK, Rosengren BE, Ljunggren O, Nethander M, Eriksson AL, Lorentzon M, Leung J, Kwok T, Orwoll ES, Ohlsson C (2017) Low testosterone, but not estradiol, is associated with incident falls in older men: the international MrOS study. J Bone Miner Res 32(6):1174-1181. https://doi. org/10.1002/jbmr.3088

47. Swiecicka A, Lunt M, Ahern T, O'Neill TW, Bartfai G, Casanueva FF, Forti G, Giwercman A, Han TS, Lean MEJ, Pendleton N, Punab M, Slowikowska-Hilczer J, Vanderschueren D, Huhtaniemi IT, Wu FCW, Rutter MK, Group ES (2017) Nonandrogenic anabolic hormones predict risk of frailty: European male ageing study prospective data. J Clin Endocrinol Metab 102(8):2798-2806. https://doi.org/10.1210/jc.2017-00090

48. Vermeulen A, Kaufman JM, Giagulli VA (1996) Influence of some biological indexes on sex hormone-binding globulin and androgen levels in aging or obese males. J Clin Endocrinol Metab 81(5):1821-1826. https://doi.org/10.1210/jcem.81.5.8626841

49. Davison SL, Bell R, Donath S, Montalto JG, Davis SR (2005) Androgen levels in adult females: changes with age, menopause, and oophorectomy. J Clin Endocrinol Metab 90(7):3847-3853. https://doi.org/10.1210/jc.2005-0212

50. Varadhan R, Walston J, Cappola AR, Carlson MC, Wand GS, Fried LP (2008) Higher levels and blunted diurnal variation of cortisol in frail older women. J Gerontol A Biol Sci Med Sci 63(2):190-195

51. Zadik Z, Chalew SA, McCarter RJ Jr, Meistas M, Kowarski AA (1985) The influence of age on the 24-hour integrated concentration of growth hormone in normal individuals. J Clin Endocrinol Metab 60(3):513-516. https://doi.org/10.1210/jcem-60-3-513

52. Sinclair AJ, Abdelhafiz AH, Rodriguez-Manas L (2017) Frailty and sarcopenia - newly emerging and high impact complications of diabetes. J Diabetes Complications 31(9):1465-1473. https:// doi.org/10.1016/j.jdiacomp.2017.05.003

53. Srikanthan P, Karlamangla AS (2011) Relative muscle mass is inversely associated with insulin resistance and prediabetes. Findings from the third National Health and Nutrition Examination Survey. J Clin Endocrinol Metab 96(9):2898-2903. https:// doi.org/10.1210/jc.2011-0435

54. Kalyani RR, Metter EJ, Egan J, Golden SH, Ferrucci L (2015) Hyperglycemia predicts persistently lower muscle strength with aging. Diabetes Care 38(1):82-90. https://doi.org/10.2337/ dc14-1166

55. Park SW, Goodpaster BH, Lee JS, Kuller LH, Boudreau R, de Rekeneire N, Harris TB, Kritchevsky S, Tylavsky FA, Nevitt M, Cho YW, Newman AB, Health A, Body Composition S (2009) Excessive loss of skeletal muscle mass in older adults with type 2 diabetes. Diabetes Care 32(11):1993-1997. https://doi. org/10.2337/dc09-0264

56. Kim J, Lee Y, Kye S, Chung YS, Kim JH, Chon D, Lee KE (2017) Diet quality and osteosarcopenic obesity in communitydwelling adults 50 years and older. Maturitas 104:73-79. https ://doi.org/10.1016/j.maturitas.2017.08.007

57. JafariNasabian P, Inglis JE, Kelly OJ, Ilich JZ (2017) Osteosarcopenic obesity in women: impact, prevalence, and management challenges. Int J Womens Health 9:33-42. https://doi. org/10.2147/IJWH.S106107

58. Veronese N, Stubbs B, Koyanagi A, Hebert JR, Cooper C, Caruso MG, Guglielmi G, Reginster JY, Rizzoli R, Maggi S, Shivappa N (2018) Pro-inflammatory dietary pattern is associated with fractures in women: an eight-year longitudinal cohort study. Osteoporos Int 29(1):143-151. https://doi.org/10.1007/s0019 8-017-4251-5

59. Shivappa N, Stubbs B, Hebert JR, Cesari M, Schofield P, Soysal P, Maggi S, Veronese N (2018) The relationship between the dietary inflammatory index and incident frailty: a longitudinal cohort study. J Am Med Dir Assoc 19(1):77-82. https://doi. org/10.1016/j.jamda.2017.08.006

60. Mohseni R, Aliakbar S, Abdollahi A, Yekaninejad MS, Maghbooli Z, Mirzaei K (2017) Relationship between major dietary patterns and sarcopenia among menopausal women. Aging Clin Exp Res 29(6):1241-1248. https://doi.org/10.1007/s4052 0-016-0721-4

61. Isanejad M, Sirola J, Mursu J, Rikkonen T, Kroger H, Tuppurainen M, Erkkila AT (2018) Association of the Baltic sea and mediterranean diets with indices of sarcopenia in elderly women. OSPTRE-FPS study. Eur J Nutr 57(4):1435-1448. https ://doi.org/10.1007/s00394-017-1422-2

62. Alvarez-Perez J, Sanchez-Villegas A, Diaz-Benitez EM, RuanoRodriguez C, Corella D, Martinez-Gonzalez MA, Estruch R, Salas-Salvado J, Serra-Majem L (2016) Influence of a mediterranean dietary pattern on body fat distribution: results of the predimed-canarias intervention randomized trial. J Am Coll Nutr 35(6):568-580. https://doi.org/10.1080/07315724.2015.1102102

63. Veronese N, Stubbs B, Noale M, Solmi M, Rizzoli R, Vaona A, Demurtas J, Crepaldi G, Maggi S (2017) Adherence to a 
mediterranean diet is associated with lower incidence of frailty: a longitudinal cohort study. Clin Nutr. https://doi.org/10.1016/j. clnu.2017.08.028

64. Kelly OJ, Gilman JC, Kim Y, Ilich JZ (2017) Macronutrient intake and distribution in the etiology, prevention and treatment of osteosarcopenic obesity. Curr Aging Sci 10(2):83-105. https ://doi.org/10.2174/1874609809666160509122558

65. Houston DK, Nicklas BJ, Ding J, Harris TB, Tylavsky FA, Newman AB, Lee JS, Sahyoun NR, Visser M, Kritchevsky SB, Health ABCS (2008) Dietary protein intake is associated with lean mass change in older, community-dwelling adults: the health, aging, and body composition (Health ABC) study. Am J Clin Nutr 87(1):150-155. https://doi.org/10.1093/ajcn/87.1.150

66. Houston DK, Tooze JA, Garcia K, Visser M, Rubin S, Harris TB, Newman AB, Kritchevsky SB, Health ABCS (2017) Protein intake and mobility limitation in community-dwelling older adults: the Health ABC study. J Am Geriatr Soc 65(8):17051711. https://doi.org/10.1111/jgs.14856

67. Kelly OJ, Gilman JC, Kim Y, Ilich JZ (2016) Micronutrient intake in the etiology, prevention and treatment of osteosarcopenic obesity. Curr Aging Sci 9(4):260-278

68. Agarwal S, Reider C, Brooks JR, Fulgoni VL 3rd (2015) Comparison of prevalence of inadequate nutrient intake based on body weight status of adults in the united states: an analysis of NHANES 2001-2008. J Am Coll Nutr 34(2):126-134. https:// doi.org/10.1080/07315724.2014.901196

69. Kim J, Lee Y, Kye S, Chung YS, Lee O (2017) Association of serum vitamin d with osteosarcopenic obesity: Korea National Health and Nutrition Examination Survey 2008-2010. J Cachexia Sarcopenia Muscle 8(2):259-266. https://doi.org/10.1002/ jcsm. 12154

70. Curtis E, Litwic A, Cooper C, Dennison E (2015) Determinants of muscle and bone aging. J Cell Physiol 230(11):2618-2625. https://doi.org/10.1002/jcp.25001

71. Wang YJ, Wang Y, Zhan JK, Tang ZY, He JY, Tan P, Deng HQ, Huang W, Liu YS (2015) Sarco-osteoporosis: prevalence and association with frailty in Chinese community-dwelling older adults. Int J Endocrinol 2015:482940. https://doi. org/10.1155/2015/482940

72. Bauer JM, Sieber CC (2008) Sarcopenia and frailty: a clinician's controversial point of view. Exp Gerontol 43(7):674-678. https ://doi.org/10.1016/j.exger.2008.03.007

73. Fried LP, Tangen CM, Walston J, Newman AB, Hirsch C, Gottdiener J, Seeman T, Tracy R, Kop WJ, Burke G, McBurnie MA, Cardiovascular Health Study Collaborative Research G (2001) Frailty in older adults: evidence for a phenotype. J Gerontol A Biol Sci Med Sci 56(3):M146-M156

74. Cooper C, Dere W, Evans W, Kanis JA, Rizzoli R, Sayer AA, Sieber CC, Kaufman JM, Abellan van Kan G, Boonen S, Adachi J, Mitlak B, Tsouderos Y, Rolland Y, Reginster JY (2012) Frailty and sarcopenia: definitions and outcome parameters. Osteoporos Int 23(7):1839-1848. https://doi.org/10.1007/s00198-012-1913-1

75. Li G, Thabane L, Papaioannou A, Ioannidis G, Levine MA, Adachi JD (2017) An overview of osteoporosis and frailty in the elderly. BMC Musculoskelet Disord 18(1):46. https://doi. org/10.1186/s12891-017-1403-x

76. Liao Q, Zheng Z, Xiu S, Chan P (2018) Waist circumference is a better predictor of risk for frailty than BMI in the communitydwelling elderly in Beijing. Aging Clin Exp Res. https://doi. org/10.1007/s40520-018-0933-X

77. Perna S, Spadaccini D, Nichetti M, Avanzato I, Faliva MA, Rondanelli M (2018) Osteosarcopenic visceral obesity and osteosarcopenic subcutaneous obesity, two new phenotypes of sarcopenia: prevalence, metabolic profile, and risk factors. J Aging Res 2018:6147426. https://doi.org/10.1155/2018/6147426
78. Fielding RA, Travison TG, Kirn DR, Koochek A, Reid KF, von Berens A, Zhu H, Folta SC, Sacheck JM, Nelson ME, Liu CK, Aberg AC, Nydahl M, Lilja M, Gustafsson T, Cederholm $T$ (2017) Effect of structured physical activity and nutritional supplementation on physical function in mobility-limited older adults: results from the VIVE2 randomized trial. J Nutr Health Aging 21(9):936-942. https://doi.org/10.1007/s1260 3-017-0936-X

79. Pahor M, Guralnik JM, Ambrosius WT, Blair S, Bonds DE, Church TS, Espeland MA, Fielding RA, Gill TM, Groessl EJ, King AC, Kritchevsky SB, Manini TM, McDermott MM, Miller ME, Newman AB, Rejeski WJ, Sink KM, Williamson JD (2014) Effect of structured physical activity on prevention of major mobility disability in older adults: the life study randomized clinical trial. JAMA 311(23):2387-2396. https://doi.org/10.1001/ jama.2014.5616

80. Moreira LD, Oliveira ML, Lirani-Galvao AP, Marin-Mio RV, Santos RN, Lazaretti-Castro M (2014) Physical exercise and osteoporosis: effects of different types of exercises on bone and physical function of postmenopausal women. Arq Bras Endocrinol Metabol 58(5):514-522

81. Bauer J, Biolo G, Cederholm T, Cesari M, Cruz-Jentoft AJ, Morley JE, Phillips S, Sieber C, Stehle P, Teta D, Visvanathan R, Volpi E, Boirie Y (2013) Evidence-based recommendations for optimal dietary protein intake in older people: a position paper from the prot-age study group. J Am Med Dir Assoc 14(8):542559. https://doi.org/10.1016/j.jamda.2013.05.021

82. Wall BT, Gorissen SH, Pennings B, Koopman R, Groen BB, Verdijk LB, van Loon LJ (2015) Aging is accompanied by a blunted muscle protein synthetic response to protein ingestion. PLoS ONE 10(11):e0140903. https://doi.org/10.1371/journ al.pone.0140903

83. Moore DR, Churchward-Venne TA, Witard O, Breen L, Burd NA, Tipton KD, Phillips SM (2015) Protein ingestion to stimulate myofibrillar protein synthesis requires greater relative protein intakes in healthy older versus younger men. J Gerontol A Biol Sci Med Sci 70(1):57-62. https://doi.org/10.1093/gerona/ glu103

84. Murphy CH, Saddler NI, Devries MC, McGlory C, Baker SK, Phillips SM (2016) Leucine supplementation enhances integrative myofibrillar protein synthesis in free-living older men consuming lower- and higher-protein diets: a parallel-group crossover study. Am J Clin Nutr 104(6):1594-1606. https://doi. org/10.3945/ajcn.116.136424

85. Rizzoli R, Biver E, Bonjour JP, Coxam V, Goltzman D, Kanis JA, Lappe J, Rejnmark L, Sahni S, Weaver C, Weiler H, Reginster JY (2018) Benefits and safety of dietary protein for bone health-an expert consensus paper endorsed by the European Society for Clinical and Economical aspects of Osteopororosis, Osteoarthritis, and Musculoskeletal diseases and by the International Osteoporosis Foundation. Osteoporos Int. https://doi. org/10.1007/s00198-018-4534-5

86. Pereira-Santos M, Costa PR, Assis AM, Santos CA, Santos DB (2015) Obesity and vitamin D deficiency: a systematic review and meta-analysis. Obes Rev 16(4):341-349. https://doi. org/10.1111/obr.12239

87. Bauer JM, Verlaan S, Bautmans I, Brandt K, Donini LM, Maggio M, McMurdo ME, Mets T, Seal C, Wijers SL, Ceda GP, De Vito G, Donders G, Drey M, Greig C, Holmback U, Narici M, McPhee J, Poggiogalle E, Power D, Scafoglieri A, Schultz R, Sieber CC, Cederholm T (2015) Effects of a vitamin D and leucine-enriched whey protein nutritional supplement on measures of sarcopenia in older adults, the provide study: a randomized, double-blind, placebo-controlled trial. J Am Med Dir Assoc 16(9):740-747. https://doi.org/10.1016/j.jamda.2015.05.021 
88. Verlaan S, Aspray TJ, Bauer JM, Cederholm T, Hemsworth J, Hill TR, McPhee JS, Piasecki M, Seal C, Sieber CC, Ter Borg S, Wijers SL, Brandt K (2017) Nutritional status, body composition, and quality of life in community-dwelling sarcopenic and non-sarcopenic older adults: a case-control study. Clin Nutr 36(1):267-274. https://doi.org/10.1016/j.clnu.2015.11.013

89. Jeromson S, Gallagher IJ, Galloway SD, Hamilton DL (2015) Omega-3 fatty acids and skeletal muscle health. Mar Drugs 13(11):6977-7004. https://doi.org/10.3390/md13116977

90. Rousseau JH, Kleppinger A, Kenny AM (2009) Self-reported dietary intake of omega-3 fatty acids. JAGS 57(10):1781-1788

91. Smith GI, Atherton P, Reeds DN, Mohammed BS, Rankin D, Rennie MJ, Mittendorfer B (2011) Dietary omega-3 fatty acid supplementation increases the rate of muscle protein synthesis in older adults: a randomized controlled trial. Am J Clin Nutr 93(2):402-412. https://doi.org/10.3945/ajcn.110.005611

92. Rondanelli M, Klersy C, Terracol G, Talluri J, Maugeri R, Guido D, Faliva MA, Solerte BS, Fioravanti M, Lukaski H, Perna S (2016) Whey protein, amino acids, and vitamin D supplementation with physical activity increases fat-free mass and strength, functionality, and quality of life and decreases inflammation in sarcopenic elderly. Am J Clin Nutr 103(3):830-840. https://doi. org/10.3945/ajen.115.113357

93. Kirn DR, Koochek A, Reid KF, von Berens Å, Travison TG, Folta S, Sacheck J, Nelson M, Liu C, Phillips E, Åberg AC, Nydahl M, Gustafsson T, Cederholm T, Fielding RA (2015) The vitality, independence, and vigor in the elderly 2 study (VIVE2): design and methods. Contemp Clin Trials 43:164-171. https:// doi.org/10.1016/j.cct.2015.06.001

94. Englund DA, Kirn DR, Koochek A, Zhu H, Travison TG, Reid KF, von Berens A, Melin M, Cederholm T, Gustafsson T, Fielding RA (2017) Nutritional supplementation with physical activity improves muscle composition in mobility-limited older adults, the VIVE2 study: a randomized, double-blind, placebo-controlled trial. J Gerontol A Biol Sci Med Sci 73(1):95-101. https ://doi.org/10.1093/gerona/glx141

95. Inglis JE, Ilich JZ (2015) The microbiome and osteosarcopenic obesity in older individuals in long-term care facilities. Curr Osteoporos Rep 13(5):358-362. https://doi.org/10.1007/s1191 4-015-0287-7

96. Bindels LB, Delzenne NM (2013) Muscle wasting: the gut microbiota as a new therapeutic target? Int J Biochem Cell Biol 45(10):2186-2190. https://doi.org/10.1016/j.biocel.2013.06.021

97. Puiman P, Stoll B, Molbak L, de Bruijn A, Schierbeek H, Boye M, Boehm G, Renes I, van Goudoever J, Burrin D (2013) Modulation of the gut microbiota with antibiotic treatment suppresses whole body urea production in neonatal pigs. Am J Physiol Gastrointest Liver Physiol 304(3):G300-G310. https://doi. org/10.1152/ajpgi.00229.2011

98. Kakkar AK, Dahiya N (2015) Drug treatment of obesity: current status and future prospects. Eur J Intern Med 26(2):89-94. https ://doi.org/10.1016/j.ejim.2015.01.005

99. Martin KA, Mani MV, Mani A (2015) New targets to treat obesity and the metabolic syndrome. Eur J Pharmacol 763(Pt A):64-74. https://doi.org/10.1016/j.ejphar.2015.03.093

100. Tella SH, Gallagher JC (2014) Prevention and treatment of postmenopausal osteoporosis. J Steroid Biochem Mol Biol 142:155170. https://doi.org/10.1016/j.jsbmb.2013.09.008

101. Reginster JY, Neuprez A, Beaudart C, Lecart MP, Sarlet N, Bernard D, Disteche S, Bruyere O (2014) Antiresorptive drugs beyond bisphosphonates and selective oestrogen receptor modulators for the management of postmenopausal osteoporosis. Drugs Aging 31(6):413-424. https://doi.org/10.1007/s4026 6-014-0179-z
102. Morley JE (2016) Pharmacologic options for the treatment of sarcopenia. Calcif Tissue Int 98(4):319-333. https://doi. org/10.1007/s00223-015-0022-5

103. De Spiegeleer A, Beckwee D, Bautmans I, Petrovic M, Sarcopenia Guidelines Development group of the Belgian Society of Geriatrics (2018) Pharmacological interventions to improve muscle mass, muscle strength and physical performance in older people: an umbrella review of systematic reviews and meta-analyses. Drugs Aging 35(8):719-734. https://doi.org/10.1007/s4026 6-018-0566-y

104. Girgis CM, Mokbel N, Digirolamo DJ (2014) Therapies for musculoskeletal disease: can we treat two birds with one stone? Curr Osteoporos Rep 12(2):142-153. https://doi.org/10.1007/s1191 4-014-0204-5

105. Reginster JY, Cooper C, Rizzoli R, Kanis JA, Appelboom G, Bautmans I, Bischoff-Ferrari HA, Boers M, Brandi ML, Bruyere O, Cherubini A, Flamion B, Fielding RA, Gasparik AI, Van Loon L, McCloskey E, Mitlak BH, Pilotto A, Reiter-Niesert S, Rolland Y, Tsouderos Y, Visser M, Cruz-Jentoft AJ (2016) Recommendations for the conduct of clinical trials for drugs to treat or prevent sarcopenia. Aging Clin Exp Res 28(1):47-58. https://doi. org/10.1007/s40520-015-0517-y

106. Bahat G, Tufan A, Tufan F, Karan MA (2016) Suggestions on sarcopenia-related trials. Aging Clin Exp Res 28(5):1029-1030. https://doi.org/10.1007/s40520-016-0601-y

107. Isidori AM, Giannetta E, Greco EA, Gianfrilli D, Bonifacio V, Isidori A, Lenzi A, Fabbri A (2005) Effects of testosterone on body composition, bone metabolism and serum lipid profile in middle-aged men: a meta-analysis. Clin Endocrinol (Oxf) 63(3):280-293. https://doi.org/10.1111/j.1365-2265.2005.02339 . $\mathrm{x}$

108. Storer TW, Basaria S, Traustadottir T, Harman SM, Pencina K, Li Z, Travison TG, Miciek R, Tsitouras P, Hally K, Huang G, Bhasin S (2017) Effects of testosterone supplementation for 3 years on muscle performance and physical function in older men. J Clin Endocrinol Metab 102(2):583-593. https://doi. org/10.1210/jc.2016-2771

109. Srinivas-Shankar U, Roberts SA, Connolly MJ, O'Connell MD, Adams JE, Oldham JA, Wu FC (2010) Effects of testosterone on muscle strength, physical function, body composition, and quality of life in intermediate-frail and frail elderly men: a randomized, double-blind, placebo-controlled study. J Clin Endocrinol Metab 95(2):639-650. https://doi.org/10.1210/ jc. 2009-1251

110. Ottenbacher KJ, Ottenbacher ME, Ottenbacher AJ, Acha AA, Ostir GV (2006) Androgen treatment and muscle strength in elderly men: a meta-analysis. J Am Geriatr Soc 54(11):16661673. https://doi.org/10.1111/j.1532-5415.2006.00938.x

111. Snyder PJ, Bhasin S, Cunningham GR, Matsumoto AM, Stephens-Shields AJ, Cauley JA, Gill TM, Barrett-Connor E, Swerdloff RS, Wang C, Ensrud KE, Lewis CE, Farrar JT, Cella D, Rosen RC, Pahor M, Crandall JP, Molitch ME, Cifelli D, Dougar D, Fluharty L, Resnick SM, Storer TW, Anton S, Basaria S, Diem SJ, Hou X, Mohler ER 3rd, Parsons JK, Wenger NK, Zeldow B, Landis JR, Ellenberg SS, Testosterone Trials I (2016) Effects of testosterone treatment in older men. N Engl J Med 374(7):611-624. https://doi.org/10.1056/NEJMoa1506119

112. Pierorazio PM, Ferrucci L, Kettermann A, Longo DL, Metter EJ, Carter HB (2010) Serum testosterone is associated with aggressive prostate cancer in older men: results from the Baltimore longitudinal study of aging. BJU Int 105(6):824-829. https://doi. org/10.1111/j.1464-410X.2009.08853.x

113. Spitzer M, Huang G, Basaria S, Travison TG, Bhasin S (2013) Risks and benefits of testosterone therapy in older men. Nat Rev Endocrinol 9(7):414-424. https://doi.org/10.1038/nrend o.2013.73 
114. Bhasin S, Brito JP, Cunningham GR, Hayes FJ, Hodis HN, Matsumoto AM, Snyder PJ, Swerdloff RS, Wu FC, Yialamas MA (2018) Testosterone therapy in men with hypogonadism: an Endocrine Society clinical practice guideline. J Clin Endocrinol Metab 103(5):1715-1744. https://doi.org/10.1210/jc.2018-00229

115. Dalton JT, Barnette KG, Bohl CE, Hancock ML, Rodriguez D, Dodson ST, Morton RA, Steiner MS (2011) The selective androgen receptor modulator gtx-024 (enobosarm) improves lean body mass and physical function in healthy elderly men and postmenopausal women: results of a double-blind, placebo-controlled phase ii trial. J Cachexia Sarcopenia Muscle 2(3):153-161. https ://doi.org/10.1007/s13539-011-0034-6

116. Liu H, Bravata DM, Olkin I, Nayak S, Roberts B, Garber AM, Hoffman AR (2007) Systematic review: the safety and efficacy of growth hormone in the healthy elderly. Ann Intern Med 146(2):104-115

117. Rudman D, Feller AG, Nagraj HS, Gergans GA, Lalitha PY, Goldberg AF, Schlenker RA, Cohn L, Rudman IW, Mattson DE (1990) Effects of human growth hormone in men over 60 years old. N Engl J Med 323(1):1-6. https://doi.org/10.1056/NEJM1 99007053230101

118. Papadakis MA, Grady D, Black D, Tierney MJ, Gooding GA, Schambelan M, Grunfeld C (1996) Growth hormone replacement in healthy older men improves body composition but not functional ability. Ann Intern Med 124(8):708-716

119. Blackman MR, Sorkin JD, Munzer T, Bellantoni MF, BusbyWhitehead J, Stevens TE, Jayme J, O'Connor KG, Christmas C, Tobin JD, Stewart KJ, Cottrell E, St Clair C, Pabst KM, Harman SM (2002) Growth hormone and sex steroid administration in healthy aged women and men: a randomized controlled trial. JAMA 288(18):2282-2292

120. Nass R, Pezzoli S, Clancy Oliveri M, Patrie J, Harrell F, Clasey J, Heymsfield S, Bach M, Lee Vance M, Thorner M (2008) Effects of an oral ghrelin mimetic on body composition and clinical outcomes in healthy older adults a randomized trial. Ann Intern Med 149(9):601-611

121. Adunsky A, Chandler J, Heyden N, Lutkiewicz J, Scott BB, Berd Y, Liu N, Papanicolaou DA (2011) Mk-0677 (ibutamoren mesylate) for the treatment of patients recovering from hip fracture: a multicenter, randomized, placebo-controlled phase IIb study. Arch Gerontol Geriatr 53(2):183-189. https://doi. org/10.1016/j.archger.2010.10.004

122. Bach MA, Rockwood K, Zetterberg C, Thamsborg G, Hebert R, Devogelaer JP, Christiansen JS, Rizzoli R, Ochsner JL, Beisaw N, Gluck O, Yu L, Schwab T, Farrington J, Taylor AM, Ng
J, Fuh V, Group MKHFS (2004) The effects of MK-0677, an oral growth hormone secretagogue, in patients with hip fracture. J Am Geriatr Soc 52(4):516-523. https://doi.org/10.111 $1 / \mathrm{j} .1532-5415.2004 .52156 . \mathrm{x}$

123. Guo B, Zhang ZK, Liang C, Li J, Liu J, Lu A, Zhang BT, Zhang G (2017) Molecular communication from skeletal muscle to bone: a review for muscle-derived myokines regulating bone metabolism. Calcif Tissue Int 100(2):184-192. https://doi. org/10.1007/s00223-016-0209-4

124. Rooks DS, Laurent D, Praestgaard J, Rasmussen S, Bartlett M, Tanko LB (2017) Effect of bimagrumab on thigh muscle volume and composition in men with casting-induced atrophy. J Cachexia Sarcopenia Muscle 8(5):727-734. https://doi.org/10.1002/ jcsm. 12205

125. Rooks D, Praestgaard J, Hariry S, Laurent D, Petricoul O, Perry RG, Lach-Trifilieff E, Roubenoff R (2017) Treatment of sarcopenia with bimagrumab: results from a phase II, randomized, controlled, proof-of-concept study. J Am Geriatr Soc 65(9):19881995. https://doi.org/10.1111/jgs. 14927

126. Garito T, Roubenoff R, Hompesch M, Morrow L, Gomez K, Rooks D, Meyers C, Buchsbaum MS, Neelakantham S, Swan T, Filosa LA, Laurent D, Petricoul O, Zakaria M (2018) Bimagrumab improves body composition and insulin sensitivity in insulin-resistant individuals. Diabetes Obes Metab 20(1):94-102. https://doi.org/10.1111/dom. 13042

127. Sumukadas D, Witham MD, Struthers AD, McMurdo ME (2007) Effect of perindopril on physical function in elderly people with functional impairment: a randomized controlled trial. CMAJ 177(8):867-874. https://doi.org/10.1503/cmaj.061339

128. Cesari M, Pedone C, Incalzi RA, Pahor M (2010) Ace-inhibition and physical function: results from the trial of angiotensin-converting enzyme inhibition and novel cardiovascular risk factors (train) study. J Am Med Dir Assoc 11(1):26-32. https://doi. org/10.1016/j.jamda.2009.09.014

129. Band MM, Sumukadas D, Struthers AD, Avenell A, Donnan PT, Kemp PR, Smith KT, Hume CL, Hapca A, Witham MD (2018) Leucine and ACE inhibitors as therapies for sarcopenia (LACE trial): study protocol for a randomised controlled trial. Trials 19(1):6. https://doi.org/10.1186/s13063-017-2390-9

Publisher's Note Springer Nature remains neutral with regard to jurisdictional claims in published maps and institutional affiliations.

\title{
Affiliations
}

\author{
Jürgen M. Bauer ${ }^{1}$. Alfonso J. Cruz-Jentoft ${ }^{2}$. Roger A. Fielding ${ }^{3}$. John A. Kanis ${ }^{4,5}$ - Jean-Yves Reginster ${ }^{6,7,8}$. \\ Olivier Bruyère ${ }^{6,7} \cdot$ Matteo Cesari $^{9} \cdot$ Roland Chapurlat $^{10} \cdot$ Nasser Al-Daghri $^{8} \cdot$ Elaine Dennison $^{11}$. \\ Jean-Marc Kaufman ${ }^{12}$. Francesco Landi ${ }^{13}$. Andrea Laslop ${ }^{14}$. Médéa Locquet ${ }^{6,7}$. Stefania Maggi ${ }^{15}$. \\ Eugene McCloskey ${ }^{16,17}$. Simone Perna ${ }^{18} \cdot$ René Rizzoli $^{7,19} \cdot$ Yves Rolland $^{20} \cdot$ Mariangela Rondanelli $^{21} \cdot$ Pawel Szulc $^{22}$. \\ Bruno Vellas $^{20} \cdot$ Mila Vlaskovska $^{23} \cdot$ Cyrus Cooper $^{7,11,24}$
}

1 Center for Geriatric Medicine, University of Heidelberg, AGAPLESION Bethanien Krankenhaus Heidelberg, Heidelberg, Germany

2 Servicio de Geriatría, Hospital Universitario Ramón y Cajal (IRYCIS), Madrid, Spain
3 Nutrition, Exercise Physiology, and Sarcopenia Laboratory, Jean Mayer USDA Human Nutrition Research Center on Aging, Tufts University, Boston, MA, USA

4 Mary McKillop Health Institute, Australian Catholic University, Melbourne, Australia

5 Centre for Metabolic Bone Diseases, University of Sheffield Medical School, Sheffield, UK 
6 Department of Public Health, Epidemiology and Health Economics, University of Liège, CHU Sart Tilman B23, 4000 Liège, Belgium

7 WHO Collaborating Centre for Public Health Aspects of Musculoskeletal Health and Aging, Liège, Belgium

8 Chair for Biomarkers of Chronic Diseases, Biochemistry Department, College of Science, King Saud University, Riyadh, Kingdom of Saudi Arabia

9 Fondazione IRCCS Ca' Granda Ospedale Maggiore Policlinico, University of Milan, Milan, Italy

10 INSERM, UMR 1033, Université de Lyon, Hôpital E Herriot, 69437 Lyon Cedex 03, France

11 MRC Lifecourse Epidemiology Unit, University of Southampton, Southampton General Hospital, Southampton, UK

12 Department of Endocrinology, Ghent University Hospital, Ghent, Belgium

13 Department of Geriatrics, Neurosciences and Orthopaedics, Orthogeriatric Unit, Teaching Hospital "Agostino Gemelli", Catholic University of the Sacred Heart School of Medicine, Rome, Italy

14 Scientific Office, Federal Office for Safety in Health Care, Austrian Agency for Health and Food Safety, Vienna, Austria
15 Aging Program, National Research Council, Padua, Italy

16 Centre for Metabolic Bone Diseases, University of Sheffield, Sheffield, UK

17 Mellanby Centre for Bone Research and Centre for Integrated Research in Musculoskeletal Ageing, University of Sheffield, Sheffield, UK

18 Department of Biology, College of Science, University of Bahrain, Sakhir Campus, P.O. Box 32038, Zallaq, Bahrain

19 Division of Bone Diseases, Geneva University Hospitals and Faculty of Medicine, Geneva, Switzerland

20 CHU Toulouse, Médecine Gériatrie Gérontopôle, Cité de la Santé, 20 Rue du Pont Saint Pierre, Inserm 1027, 31059 Toulouse, France

21 IRCCS Mondino Foundation, Pavia, Department of Public Health, Experimental and Forensic Medicine, Unit of Human Nutrition, University of Pavia, Pavia, Italy

22 INSERM, UMR 1033, University of Lyon, Hôpital Edouard Herriot, Lyon, France

23 Medical Faculty, Department of Pharmacology, Medical University Sofia, 2, Zdrave Str, 1431 Sofia, Bulgaria

24 NIHR Musculoskeletal Biomedical Research Unit, University of Oxford, Oxford, UK 